\title{
OCCURRENCE OF DIGENEAN LARVAE IN FRESHWATER SNAILS IN THE RUVU BASIN, TANZANIA
}

\author{
G Nkwengulila ${ }^{1}$ and ESP Kigadye ${ }^{2}$ \\ ${ }^{1}$ Department of Zoology and Marine Biology, University of Dar es Salaam, \\ P.O. Box 35064, Dar es Salaam, Tanzania. E-mail: gamba@udsm.ac.tz \\ ${ }^{2}$ Department of Zoology, The Open University of Tanzania, \\ P.O. Box 23409, Dar es Salaam, Tanzania. E-mail: ekigadye2002@yahoo.co.uk
}

\begin{abstract}
A survey was carried out on digenean larvae infecting freshwater snails in five habitats in Dar es Salaam, Ruvu and Morogoro. 9424 snails belonging to 12 species from five families were examined for digenean infection from July 1996-June 1997. 20 morphologically distinguishable cercariae were recovered. Multiple infections were not recorded. While the general prevalence of digeneans in snails was low (3.5\%), variations occurred between seasons, among habitats and snail host species. Prevalence was high during the dry season but low in the rain season. Among habitats, highest prevalence was recorded at Kinondoni pond and lowest at Ruvu ponds, and was highest in Lymnaea natalensis followed by Bulinus tropicus but was lowest in Bulinus nasutus.
\end{abstract}

\section{INTRODUCTION}

Several studies to establish the prevelance of Schistosoma mansoni and S. haematobium (McCullough et al. 1968, Baalawy and Moyo 1970, Rugemalila 1991) in populations of their snail intermediate hosts have been undertaken in east Africa. Some attention has been given to the prevalence of bovine schistosomiasis in Bulinus snails (Berrie 1970, Kasuku et al. 1988) and of Fasciola gigantica in populations of Lymnaea natalensis (Ogambo-Ongoma 1971). However, relatively little information on the abundance, morphology and host relationships of other east African trematodes species not of medical or veterinary importance has accumulated (Fain 1953, Vercammen-Grandjean 1960, Loker et al. 1980).

Such studies may be useful in a number of ways. They may reveal species that could be useful as biological agents in the control of snail transmitted diseases (Haas 2000). For instance, McCullough (1981) reported that the prevalence of Schistosoma haematobium in Bulinus species might be reduced drastically by antagonist larval echinostomes naturally present in an endemic area.
The present study was undertaken as a preliminary step to define the digenetic trematode fauna in a geographic area in which S. haematobium and S. mansoni are endemic. It was hoped that this investigation could provide useful background information on future studies interested in the biological control of these diseases.

\section{MATERIALS AND METHODS The Habitats \\ Mindu dam}

This is a reservoir for domestic and industrial use for the Morogoro municipality. It also serves for irrigation and flood control down stream. It has an area of 400 hectares, maximum depth $11 \mathrm{~m}$, and is located $10 \mathrm{~km}$ to the South West of Morogoro Municipality off the main road to Iringa in the Southern Highlands. The snail fauna collected from Mindu dam comprised of Bulinus tropicus Krauss 1842, Bulinus forskalii Ehrenberg 1831, Bellamya capillata Fruenfeld 1869 and Biomphalaria pfeifferi Krauss 1848. 


\section{Ruvu}

At Ruvu snails were collected from fishponds owned by The National Food Corporation (NAFCO). The fishponds are constructed along Ruvu River flood plain and receive water directly from the Ruvu River. The Ruvu drains from Uluguru Mountains south of Morogoro. It also receives water from the Ngerengere River, which has its origins west of the Uluguru Mountains, crosses Mindu dam and flows eastwards to eventually empty into the Ruvu. The snail fauna collected included Bulinus nasutus Martens 1875, B. forskalii, Cleopatra ferruginea Lea and Lea 1850 and Lanistes stulhamanni Martens 1897.

\section{Kinondoni pond}

This is a shallow pond about $200 \mathrm{~m}$, located near Kinondoni primary court in Kinondoni district. It is rich in aquatic vegetation, particularly water lilies. Snails collected were Lymnaea natalensis Krauss 1848, Helisoma duryi Wetherby 1879, B. foskalii and Gyraulus costulatus Krauss 1848.

\section{Mbezi pond}

This is an oval shaped pond that covers about $100 \mathrm{~m}^{2}$, located in Mbezi area just off Morogoro road. The pond serves for watering domestic animals, and is visited by aquatic birds throughout the year. The snail fauna collected comprised of Bulinus globosus Morelet 1866, B. forskalii and Melanoides tuberculata Muller 1774.

\section{The stream at the University}

This is an ephemeral stream that crosses through rice fields south of the playgrounds at the main campus of the University of Dar es Salaam. Only B. forskalii was obtained from this stream.

\section{Methods}

Snails were collected monthly from July 1996 to June 1997 from the five sites described above; Mindu dam in Morogoro, fish ponds at Ruvu NAFCO farms, natural ponds at Kinondoni and Mbezi and from a stream at the main campus of the University of Dar es Salaam (Fig. 1). Collection and transportation of snails to the laboratory at the University of Dar es Salaam was carried out as described by the Danish Bilharziasis Laboratory (1987).

In the laboratory, snails were isolated singly in $10 \mathrm{ml}$ beakers filled with conditioned water and exposed to strong artificial light (60 watts at one meter) for six to twenty four hours to stimulate shedding of cercariae. The beakers were inspected for presence of cercariae every four hours under a dissecting microscope.

The nomenclacture used for Tanzania species of freshwater snails was that proposed by the Danish Bilharziasis Laboratory (1987) for eastern Africa freshwater snails. Specimens were identified with the help of keys by Miller (1926), Nasir and Erasmus (1964), Dawes (1966), Frandsen and Christensen (1984) and literature available. Specimens were compared with existing descriptions of African cercariae and were classified as 'undescribed' if not closely corresponding to decribed species. Sufficient information on size, flame cell patterns, stylet shapes, collar spines counts etc. (Kigadye 1998) was collected in most cases to unambiguously recognize the cercariae, but time did not permit exhaustive description of all the morphological features of each species of cercariae recovered. 


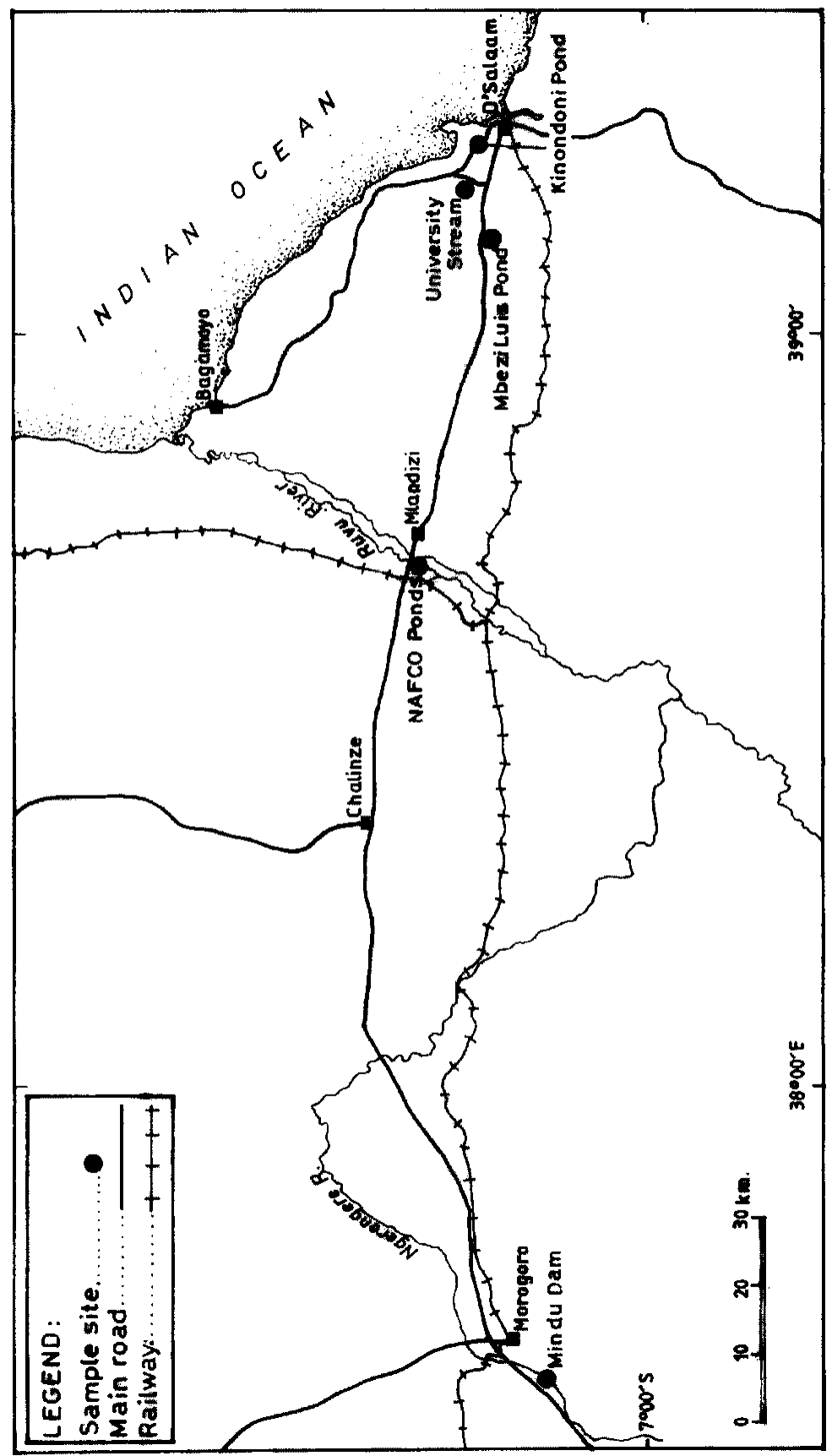

Figure 1: Sampling sites 
Nkwengulila and Kigadye - Occurrence of digenean larvae in fresh water snails ...

\section{RESULTS}

A total of 9,424 snails were examined, of these $331(3.5 \%)$ were infected by digenean trematodes. The global prevalence of natural infection in host snails were $10.3 \%$ in Lymnaea natalensis out of 832 snails, $8.2 \%$ (2053) in Bulinus tropicus, 2.4\% (888) in Bellamya capillata, 2.1\% (476) in Gyraulus costulatus, $2.1 \%$ (1312) in Bulinus globosus, 2\% (397) in Bulinus forskalii, $1.2 \%$ (597) in Cleopatra ferruginea, $1.0 \%$ (286) in Biomphalaria pfeifferi and $0.8 \%$ (198) in Bulinus nasutus. No infection was found in Melanoides tuberculata, Helisoma duryi and Lanistes stulhalmanni (Table 1).

Table 1: $\quad$ Summary of snail collections

\begin{tabular}{llccc}
\hline Habitat & Host snail species & $\begin{array}{c}\text { Number } \\
\text { collected }\end{array}$ & $\begin{array}{c}\text { Number } \\
\text { infected }\end{array}$ & $\begin{array}{c}\text { Prevalence } \\
\text { (\%) }\end{array}$ \\
\hline Kinondoni & Lymnae natalensis & 832 & 86 & 10.3 \\
pond & Gyraulus costulatus & 476 & 20 & 2.1 \\
& Bulinus forskalii & 53 & 0 & 0 \\
Mindu dam & Helisoma duryi & 538 & 0 & 0 \\
& Bulinus tropicus & 2053 & 168 & 8.2 \\
& Bellamya capillata & 888 & 22 & 2.4 \\
& Biomphalaria pfeifferi & 286 & 3 & 1.0 \\
& Bulinus forskalii & 66 & 0 & 0 \\
Ruvu pond & Bulinus forskalii Cleopatra & 75 & 1 & 1.3 \\
& ferruginea & 597 & 7 & 1.2 \\
& Bulinus nasatus & 198 & 1 & 0.2 \\
Mbezi pond & Lanistes stulhamani & 138 & 0 & 0 \\
& Bulinus globusus & 1312 & 28 & 2.1 \\
Bulinus forskalii & 97 & 1 & 1.03 \\
University & Melanoides tubercullata & 1574 & 0 & 0 \\
stream & Bulinus forskalii & 43 & 1 & 2.3 \\
Total & & 9424 & 331 & 3.5 \\
\hline
\end{tabular}

Table 2: $\quad$ Occurrence of cercariae in snail hosts from the Ruvu Basin

\begin{tabular}{|c|c|c|c|c|c|}
\hline Habitat & $\begin{array}{c}\text { Cercarial } \\
\text { no. }\end{array}$ & $\begin{array}{c}\text { Morphological } \\
\text { Category }\end{array}$ & Snail host & $\begin{array}{c}\text { Prevalence }(\%) \\
\text { No. of snails } \\
\end{array}$ & Identification \\
\hline \multirow{9}{*}{$\begin{array}{l}\text { Mindu } \\
\text { dam }\end{array}$} & II & Furcocercaria (BAD) & B. pfeifferi & $1.0(286)$ & \\
\hline & & & & & $\begin{array}{l}\text { S. mansoni } \\
\text { Sambon, } 1907\end{array}$ \\
\hline & $\mathrm{V}$ & Furcocercaria (LPD) & B. pfeifferi & $0.1(286)$ & \\
\hline & & & & & Undescribed \\
\hline & IV & Furcocercaria (BAD) & B. pfeifferi & $0.1(286)$ & $\begin{array}{l}\text { Schistosoma sp. } \\
\text { (reptilian) }\end{array}$ \\
\hline & VIII & Furcocercaria (BAD) & B. tropicus & $0.04(2053)$ & $\begin{array}{l}\text { Cercaria sp.nr. } \\
\text { ocellata La Valette, } \\
1855\end{array}$ \\
\hline & $\mathrm{X}$ & Echinostome & B. forskalii & $1.5(66)$ & $\begin{array}{l}\text { Cercaria sp. nr. } \\
\text { decora Fain, } 1953\end{array}$ \\
\hline & $\mathrm{XI}$ & Echinostome & B. tropicus & $0.25(397)$ & Undescribed \\
\hline & XV & Xiphidiocercaria & B.capillata & $2.4(888)$ & $\begin{array}{l}\text { Cercaria sp. nr. } \\
\text { kunga } \text { Fain, } 1953\end{array}$ \\
\hline
\end{tabular}


Tanz. J. Sci. Vol 31(2) 2005

\begin{tabular}{|c|c|c|c|c|c|}
\hline \multirow{7}{*}{$\begin{array}{l}\text { Ruvu } \\
\text { ponds }\end{array}$} & $\mathrm{V}$ & & & & \\
\hline & $\sqrt{1}$ & гücoercanta (LFD) & C. Jerruginea & $0.25(391)$ & Uirdescrioed \\
\hline & VII & Furcocercaria (BAD) & B. nasatus & $0.5(198)$ & $\begin{array}{l}\text { Schistosoma sp. } \\
\text { (avian) }\end{array}$ \\
\hline & IX & Furcocercaria (LPM) & C. ferruginea & $0.3(597)$ & $\begin{array}{l}\text { Cercaria sp. nr. } \\
\text { vivax Sonsino, } \\
1892\end{array}$ \\
\hline & XVII & Gymnocephalous & C. ferruginea & $0.8(597)$ & $\begin{array}{l}\text { Sphaeridiotrema } \\
\text { sp. nr. globolus }\end{array}$ \\
\hline & $X X$ & Paranleurolonhocerc & C. ferruginea & 01 (507) & Szidat, 1937 \\
\hline & & us & & & \\
\hline \multirow{4}{*}{$\begin{array}{l}\text { Mbezi } \\
\text { pond }\end{array}$} & I & Furcocercaria (BAD) & B. globosus & $0.4(1312)$ & S. haematobium \\
\hline & III & Furcocercous (BAM) & B. globosus & $0.4(1312)$ & Undescribed \\
\hline & XII & Echinostome & B. globosus & $0.8(1312)$ & Undescribed \\
\hline & XIII & Echinostome & B. forskalii & $1.0(97)$ & Undescribed \\
\hline \multirow{2}{*}{$\begin{array}{l}\text { Kinondon } \\
\text { i pond }\end{array}$} & XIV & Xiphidiocercaria & L. natalensis & $10.4(832)$ & Undescribed \\
\hline & XIX & Tailless & G. costulatus & $2.1(476)$ & Undescribed \\
\hline $\begin{array}{c}\text { University } \\
\text { stream }\end{array}$ & XVIII & Monostome & B. forskalii & $2.3(43)$ & Undescribed \\
\hline
\end{tabular}

The most prevalent cercariae were Cercaria no. XIV (10.4\%) recovered from $L$. natalensis at Kinondoni pond and Cercaria no. XI $(8.2 \%)$ from B. tropicus at Mindu dam. The least prevalent was Cercaria no. VIII $(0.04 \%)$ from B. tropicus at Mindu dam (Table 2).

The two most prevalent cercariae (nos. XIV and XI) showed different seasonal patterns of prevalence in their respective hosts (Fig. 2). The prevalence of Cercariae no. XIV in $L$. natalensis from Kinondoni pond was erratic but generally high during the period from July-December 1996, crashed to 0 from January-March 1997, increased slightly during the rainy season (April-May 1997) and dropped to 0 in June 1997 (Fig 2).

The prevalence of Cercaria no. XI (an echinostome) in B. tropicus at Mindu dam was high from July-November 1996, reaching a peak in September 1996 (June-
October, long dry season) (10.8\%). Prevalence was low from December 1996 through January and February 1997 (short dry season), and dropped to 0 from MarchMay 1997 (rainy season) and started to increase again in June 1997 (Fig. 2).

No individual snail was infected with more than one species of Digenea (multiple infections). However, some populations of snails were infected by more than one species of Digenea. B. globosus population at Mbezi pond for instance, harboured two furcocercous cercariae (Nos. I \& III) and one echinostome cercaria (No. XII) (Table 2). At Ruvu ponds, $C$. ferruginea was also infected by three species of digenean larvae (Cercaria no. IX, XVII and XX) but their distribution in time did not form a specific pattern as each individual cercariae was encountered once in a period of one year. 


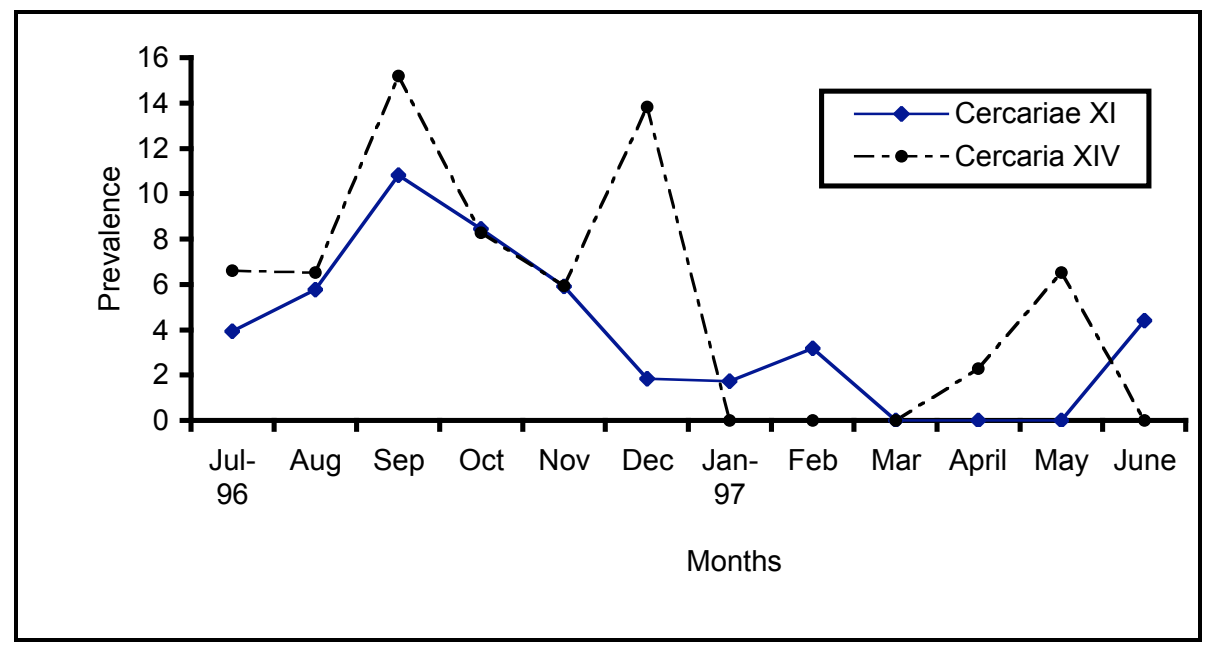

Figure 2: Monthly prevalences of Cercaria no. XIV in Lymnae natalensis from Kinondoni pond and Cercaria no. XI in Bulinus tropicus from Mindu dam.

\section{DISCUSSION}

Several studies on the occurrence of digenen larvae in their snail hosts has been undertaken in east and central Africa (Fain 1953, Vercammen-Grandjean 1960, Loker et al. 1980). The studies revealed many described and undescribed digenean species which varied spatially and in abundance. The results of the present study are compared with those of previous studies.

In Loker et al. (1980) one snail species $B$. pfeifferi yielded the greatest number of cercariae with 14 distinguishable cercariae, and the highest prevalence of infection was reported in L. natalensis $(36.9 \%)$. In the present study the greatest number of cercariae occurred in Bulinus forskalii with five distinguishable cercariae while the highest prevalence of infection was recorded in $L$. natalensis. With the exception of $S$. mansoni and S. haematobuim, there was little similarity between the cercariae observed in the present study and those reported by Loker et al. (1980) in Mwanza Tanzania. The prevalence of the two cercariae in Mwanza was as follows: $S$. mansoni (4.1\%), S. haematobuim (3.3\%) while in the present study S. mansoni (1.0\%) and $S$. haematobuim (0.4\%). Loker et al. (1980) examined snails from non-lacustrine habitats in Mwanza area while in the present study snails were collected from the Ruvu basin about $800 \mathrm{~km}$ to the east of Mwanza.

In the present study, xiphidiocercariae were the most prevalent $(10.4 \%)$ trematodes (Table 1). Similar results were obtained by Loker et al. (1980) in Mwanza region. The present study also recorded a low general prevalence $(3.5 \%)$ of digeneans in their snail hosts. This is typical of infection by digenean larvae in snails (Loker et al. 1980, Anderson and May 1979, Esch and Fernandez 1993). Moreover, the results also showed considerable variation of prevalence and diversity of trematode fauna among the five habitats studied (Table 2). Several factors may explain this variation; all habitats sampled had distinct snail faunas, for example $L$. natalensis was found at Kinondoni pond only, and B. pfeifferi and B. tropicus at Mindu Dam only. Only B. forskalii occurred at four sites (Mbezi, Mindu, Ruvu and University of Dar es Salaam). Moreover, prevalence may also 
vary on spatial dimensions as influenced by snail hosts, parasite life cycle, and nature and accessibility of habitats by infected definitive hosts (Smith 2001).

In the present study, higher prevalence levels were recorded during the dry season than in the rainy season. Other workers (Chandiwana et al. 1987, Vareyrynen et al. 2000) have reported seasonal variation of prevalence of digeneans in snails. High prevalence during the dry season has been attributed to the reduced water volume in conjunction with the increased density of snail hosts and intensified use of the habitat by definitive hosts (Sapp and Esch 1994).

This study has further confirmed the endemicity of schistosomiasis in the study area as many others have done (Rugemalila 1991). On the other hand, digeneans of veterinary importance e.g. Fasciola hepatica and paramphistomes were conspicuously absent even though their snail hosts $L$. natalensis and B. globosus, respectively, were among snails examined. This perhaps is not surprising, as pastoral activities are rare around the water bodies surveyed. Future changes in land use i.e. increased pastoral activities around the habitats may introduce digeneans of veterinary importance in these habitats.

The present study has established the occurrence of numerous species of digenean larvae in Tanzania. Nevertheless, much additional work is needed to elucidate the biology of the many trematodes species reported, and of other as yet undiscovered species in their snail hosts.

\section{ACKNOWLEDGEMENT}

The authors wish to thank the Open University of Tanzania and Tanzania Commission for Science and Technology (COSTECH) for financial support during this study. Special thanks to Prof. E S. Loker of the Department of Biology University of New Mexico for supplying some literature and encouragement.

\section{REFERENCES}

Anderson RM and May RM 1979 Prevalence of schistosome infection with molluscanpopulations: Observed patterns and theoretical predictions. Parasitology 79: 63-94.

Baalawy SS and Moyo HG 1970 Studies on population dynamics of $B$. $(P)$ nasatus and natural $S$. haematobium infection rates in relation to rainfall at Misungwi and Usagara Mwanza. East Africa Medical Journal 47: 472-478.

Berrie AD 1970 Snail problems in African schistosomiasis. Advances in Parasitology 4: 43-84.

Chandiwana SK, Christensen NØ, and Frandsen F 1987 Seasonal patterns in the transmission of Schistosoma haematobium, $S$. mattheei and $S$. mansoni in the highveld of Zimbabwe. Acta Tropica 44: 433-443.

Danish Bilharziasis Laboratory 1987 A field guide to African freshwater snails. II. East African species: $51 \mathrm{pp}$.

Dawes B 1966 The Trematoda. Cambridge University Press London.

Esch GW and Fernandez JC 1993 A functional biology of parasitism: ecology and evolutionary implications. London, Chapman and Hall.

Fain A 1953 Contribution à l'étude des formes larvaires des trématodes au Congo Belge et spécialement de la larve de Schistosoma mansoni. Méimoires Institut Royal Colonial Belge. Section des Science Naturelles et Medicales 22: 1-312.

Frandsen F and Christensen NØ 1984 An introductory guide to the identification of cercariae from African freshwater snails with special reference to cercaria of trematode species of medical and veterinary importance. Acta tropica 41: 181-202.

Haas W 2000 Echinostomes as experimental models for biological research. In Fried B and Graczyk TK (eds) The behavioural biology of echinostomes Wallingford, $\mathrm{CAB}$ International. 
Kasuku A, Christensen NØ, Monrad J, Nansen $P$ and Knudsen J 1988 Epidemiological studies on Schistosoma bovis in Iringa Region, Tanzania. Acta Tropica 44: 433-443.

Kigadye ESP 1998 Studies on larval digeneans infecting fresh water snails. MSc thesis. Department of Zoology and Marine Science, University of Dar es Salaam.

Loker ES, Moyo HG and Gardner SL 1980 Trematode-gastropod associations in nine non-lacustrine habitats in the Mwanza region of Tanzania. Parasitology 83: 381-399.

McCullough FS, Eyakuze VM, Msinde J and Nditi H 1968 Water resources and bilharziasis transmission in the Misungwi area, Mwanza district, northern Tanzania. East Africa Medical journal 45: 295-308.

McCullough FS 1981 Biological control of the snail intermediate hosts of human spp: a review of the present status and future prospects. Acta Tropica: 5-14.

Miller HM 1926 Comparative studies on furcocercous cercariae. Illinois Biological 10: $1-112$.

Nasir P and Erasmus DA 1964 A key to the cercariae from British Freshwater.
Journal of Helminthology XXXVIII: 245-268.

Ogambo-Ongoma AH $1971 \quad$ Field epidemiology of fascioliasis in Port Bell Uganda. Bulletin of Epizootic Diseases of Africa 19: 341-351.

Rugemalila JB 1991 Schistosomiasis. In Mwaluko GMP, Kilama WL, Mandara MP, Murru $\mathrm{M}$ and McPherson CNL (Eds) Health and Diseases in Tanzania. London, Harper Collins Academic.

Sapp KK and Esch GW 1994 The effect of spatial and temporal heterogeneity as structuring forces for parasite communities in Helisoma anceps and Physa gyrina. The American Midland Naturalist 132: 91-103.

Smith NF 2001 Spatial heterogeneity in recruitment of larval trematodes to snail intermediate hosts. Oecologia 127: 115122.

Vaeyrynen T, Siddal R, Valtonen ET and Taskinen J 2000 Patterns of trematode parasitism in lymnaeid snails from northern and central Finland. Annalels Zoologici Fennici 37: 189-199.

Vercammen-Grandjean P.H 1960 Les trematodes du Lac Kivu sud. Musee Royalde L'Afique Centrale, Tervuren. Belgique-Annales-Novelle serie in $4^{\circ}$ Sciences Zoologique 5: 1-171. 